\title{
DEZINFORMACJA, PROPAGANDA I WALKA PSYCHOLOGICZNA PODCZAS KONFLIKTU W ZATOCE PERSKIEJ 1990-1991
}

\footnotetext{
$\mathrm{P}$ ionierem zachodniej teorii strategii był Carl von Clausewitz, według którego wojna stanowiła przedłużenie poczynań politycznych zmierzających do złamania woli strony przeciwnej. ${ }^{1}$ Gdy spojrzymy na ostatnie konflikty zbrojne XX wieku, mając w pamięci te słowa, uświadomimy sobie, że znacznie różniły się od tych w niedalekiej przeszłości. Wojna przestała być tylko działaniem zbrojnym, zmierzającym do fizycznego unieszkodliwienia przeciwnika, zyskała wymiar „sztuki wprowadzania wroga w błąd”". Zmienia się ponadto sam charakter działań militarnych - niezmienny jest udział przemocy zbrojnej, ale coraz więcej zmagań przenosi się do przestrzeni symbolicznej ${ }^{3}$, jak np. walka informacyjna oraz propaganda. Ewolucja sposobu prowadzenia wojny rozpoczęła się po klęsce Amerykanów w Wietnamie, okupionej olbrzymimi stratami w ludziach i sprzęcie. Ameryka chciała odtąd wygrywać wojny minimalizując własne straty oraz przy dużej uwadze poświęcanej na tworzenie własnego pozytywnego wizerunku. Zdecydowano się więc na przebudowę sił zbrojnych, co przejawiało się we wdrażaniu na olbrzymią skalę najnowszych technologii elektronicznych do uzbrojenia.

„Dezinformacja może być skuteczna tylko, jeśli cel w jakiejś mierze współdziała i jeśli jest ona prowadzona za pośrednictwem mass medion" ". Technika zmienia wojnę, która toczy się w obecności mediów,

${ }^{1}$ Por. C. von Clausewitz, O wojnie, Test, Lublin 1995.

${ }^{2}$ S. Tzu, Sztuka wojenna, Przedświt, Warszawa 1994, s. 80.

${ }^{3}$ Por. L. Ciborowski, Walka informacyjna, Adam Marszałek, Toruń 2001, s. 87.

${ }^{4}$ V. Volkoff, Dezinformacja, orę̇ं wojny, Delikon, Warszawa 1991, s. 13.
} 
przedstawiających błyskawiczne relacje i przekazujących informacje. Telewizyjne sprawozdania na żywo lub w czasie bliskim rzeczywistemu, dają niezwykłe możliwości przeciwnikom w wojnie propagandowej i dezinformacji. Popyt na natychmiastowy dostęp do informacji w nadchodzących dekadach będzie się zwiększał. „Od razu nasuwa się myśl, że relacje na żywo i niemal nieograniczony dostęp mediów niekoniecznie pociaga za sobą brak cenzury lub manipulacji. Może się dziać wręcz przeciwnie: w cywilizacji, która przyzwyczai się do szybkiego dostępu do nowin, dla nadawcy będą się liczyły raczej natychmiastowo przekazywane obrazy niż dostęp do rzetelniejszych, lecz mniej widowiskowych i wolniej napływajacych informacji" ". Sytuacją tą szybko zainteresowało się wojsko, daje bowiem sposobność wprowadzenia nowych form kontroli nad przepływem wiadomości z pola bitwy do domów. Wojna w Zatoce Perskiej pokazała, czego można dokonać w tej dziedzinie. „W Zatoce Perskiej dziennikarze musieli przebywać w hotelach na tyłach; od czasu do czasu zabierano ich tylko na krótkie, zorganizowane wycieczki do punktów stacjonowania sił bardzo daleko od frontu i karmiono tym, co mogło stanowić podstawę dobrej relacji telewizyjnej. Przez system pompowane były informacje, dla wojskowych trywialne, lecz dla innych niezwykle ciekawe: obrazy inteligentnych bomb w stylu gier video; fajerwerki, gdy nadlatujace SCUDy spotykały się z pociskami Patriot; wyrzutnie rakiet $\mathrm{w}$ kłębach dymu wystrzeliwujące pociski w kierunku Iraku, poza horyzont...Przecież front znajdował się zupełnie gdzie indziej. Podczas całej wojny nie pokazano za to ani jednego zabitego żołnierza aliantów". Ale wróćmy do początku.

Saddam Husajn kontrolował sytuację w Iraku już od przełomu lat 60 . i 70. Po krwawej wojnie z Iranem, której pomimo olbrzymiego wsparcia Kuwejtu, Arabii Saudyjskiej ${ }^{7}$ i państw zachodnich nie udało mu się wygrać, szukał nowych zdobyczy. Kolejnym celem Husajna stał się Kuwejt, którego niepodległość Irak od dawna kwestionował. Od stuleci owe tereny podlegały Bagdadowi, później Turcji. Już w 1961 roku, w momencie wycofania się wojsk angielskich stacjonujących tam od czasów I wojny światowej, Irak wysuwał pretensje do niewielkiego, acz zasobnego w ropę emiratu, określanego w propagandzie irackiej jako „szyb naftowy przekształcony w państwo"

\footnotetext{
${ }^{5}$ F. Heisbourg, Wojny. Prognozy XXI wieku, Prószyński i Spółka, Warszawa 1998, s. 19.

${ }^{6}$ Tamże, s.19-20.

${ }^{7}$ Kuwejt i Arabia Saudyjska udzieliły wtedy Irakowi pomocy finansowej w wysokości 30 miliardów dolarów.

8 P. Salinger, E. Laurent, Kryzys w Zatoce Perskiej, Oficyna Literacka, Kraków 1991, s. 33.
} 
Podczas szczytu Arabskiej Rady Współpracy w Ammanie w marcu 1990 roku Husajn miał oświadczyć: „Potrzebuję dolarów (...). Powiedzcie tym w Arabii Saudyjskiej i nad Zatoką, że jeśli tych pieniędzy nie dostanę, to sam sobie je wezmę"9. Zdaniem analityków Irak rozpoczął wówczas grę, której finałem miało być opanowanie Kuwejtu i zmuszenie tym samym arabskich monarchii znad Zatoki do ustępliwości. Aby ukryć swój zasadniczy cel, rozpoczął kampanię antyamerykańską i antyizraelska, majacca na celu zjednanie sobie arabskich mas, wśród których pragnął uchodzić za męża opatrznościowego, gotowego przeciwstawić się głównym wrogom narodu arabskiego. Wkrótce pojawiły się żądania wycofania sił amerykańskich z wód Zatoki oraz wezwania Arabów do walki o wyzwolenie Jerozolimy. Głośne stały się zwłaszcza groźby irackiego przywódcy, który zapowiedział zniszczenie połowy Izraela przy użyciu broni chemicznej, gdyby ten zdecydował się zaatakować Irak.

Od lipca 1990 roku ruszyła iracka kampania antykuwejcka. Oskarżano rząd Kuwejtu o umyślne przekraczanie limitów wydobycia ropy, sztuczne obniżanie jej ceny, przywłaszczanie surowca pochodzącego z pola Rumaila (leży po obu stronach granicy) na kwote 2,4 miliarda dolarów, przesunięcie linii granicznej o 4 kilometry na niekorzyść Iraku, prowadzenie polityki jawnie proamerykańskiej i przygotowywanie obcej interwencji. Władze w Bagdadzie kolejny raz zażądały umorzenia dotychczasowych i przyznania nowych pożyczek oraz odstapienia wysp Warba i Bubijan, które Kuwejt użyczył Irakowi na czas wojny $z$ Iranem. Cała ta kampania miała na celu przekonanie Arabów, że to Irak jest strona poszkodowana i że to Kuwejtczycy zdradzili interesy regionu. „To jest naprawdę nieprawdopodobne podkreślał iracki minister Aziz - aby taki mały kraj mógł podjać działania zmierzające w kierunku zniszczenia gospodarki Iraku i destabilizacji jego systemu politycznego, nie posiadając wsparcia ze strony jakiegoś wielkiego mocarstwa" ${ }^{\prime 10}$. Tym mocarstwem w domyśle miały być Stany Zjednoczone.

Jeszcze 25 lipca 1990 roku amerykańska ambasador w Bagdadzie, April Glaspie, spotkała się z Husajnem. Podczas rozmowy iracki przywódca usłyszał od niej, że Stany Zjednoczone nie opowiedzą się po żadnej ze stron w sporze iracko-kuwejckim. Jakby na potwierdzenie tych słów 02.08 .1990 r. przed południem na codziennym spotkaniu z prasa

\footnotetext{
${ }^{9}$ W. Szymborski, Zatoka Perska, Wers, Bydgoszcz 1999, s. 119.

10 Tenże, Wojna w Zatoce, „Sprawy Międzynarodowe”, 1997, nr 4.
} 
George Bush oświadczył, że nie przewiduje interwencji amerykańskiej ${ }^{11}$. Może Saddam zinterpretował te słowa jako „zielone światło” na zajęcie Kuwejtu...

Wojska Husajna w błyskawicznym ataku 02.08.1990 r. zdobyły emirat Kuwejtu, którego władca zbiegł do Arabii Saudyjskiej. Już 7 sierpnia Bagdad ogłosił, że Kuwejt przestaje istnieć jako niepodległe państwo oraz, że od tej pory jest już tylko dziewiętnasta prowincją Iraku i w związku z tym ambasady wszystkich państw powinny być jak najszybciej zlikwidowane. Te zdarzenia zaszokowały cały świat. Nawet raporty CIA nie przewidywały, że Irak może zaatakować. Poza tym eksperci do spraw Bliskiego Wschodu utrzymywali, że nawet jeśli Irak miałby wkroczyć do Kuwejtu, to zająłby jedynie pewne kwestionowane terytoria. Ponieważ Arabowie prawdopodobnie pogodziliby się z taka aneksja, to czemu nie miałby zrobić tego Waszyngton? Husajn dobrze przewidział początkową reakcję większości krajów arabskich, które przyjęły postawę wyczekującą i patrzyły, co dalej zrobią USA. Słusznie przewidywał także, że jego posunięcie wprawi w osłupienie cały świat zachodni, ale pomylił się licząc na pobłażliwość światowej opinii publicznej $j^{12}$. Nie był w stanie przewidzieć jak wielki gniew wywoła swym krokiem w Stanach Zjednoczonych, zaniepokojonych zagarnięciem głównych źródeł zaopatrzenia Zachodu w ropę. USA poczuły się bezpośrednio zagrożone przez fakt potencjalnej dominacji Iraku w najbardziej roponośnym rejonie świata. Tak naprawdę jednak zaniepokojenie wśród elit politycznych wzbudziło bezpośrednie naruszenie interesów państw. Nastapiło bowiem zachwianie kruchej równowagi sił w rejonie Zatoki, co mogło przyspieszyć destabilizację sytuacji polityczno-wojskowej na Bliskim Wschodzie oraz wywołać perturbacje gospodarcze w skali globalnej. Stany Zjednoczone udzieliły gwarancji innym krajom Zatoki Perskiej, rozpoczynając jednocześnie ofensywę polityczną na Irak. $\mathrm{Na}$ państwo nałożone zostały sankcje gospodarcze, a wszelkie aktywa i konta kuwejckie zostały zablokowane, by reżim nie mógł $z$ nich skorzystać. Ponadto na forum Rady Bezpieczeństwa ONZ 29.11.1990 r. wyrażono zgodę na użycie przeciwko agresorowi wszelkich środków, o ile do stycznia 1991 roku nie wycofa się z zajętych terenów.

\footnotetext{
${ }^{11}$ Por. R. Bielecki, Pustynna Burza, Wydawnictwo Bellona, Warszawa 1991, s. 31.

12 „Uważano, że poza słownymi deklaracjami i ewentualnym zerwaniem stosunków dyplomatycznych oraz więzi gospodarczych, nikt nie zaryzykuje wojny przeciwko czwartej, co do wielkości, armii świata”. Zob. J. Biziewski, Pustynna Burza, Wydawnictwo Altair, Warszawa 1994, s. 6.
} 
Bagdad oświadczył, że Irak nie wycofa się z Kuwejtu. W wyniku braku jakichkolwiek działań ze strony Iraku Amerykanie przystapili do organizowania koalicji, która miała wyzwolić Kuwejt. W jej skład oprócz USA weszły jeszcze m.in. Wielka Brytania, Francja, Arabia Saudyjska, Maroko, Egipt i Syria - łącznie 28 państw. Stany Zjednoczone, które objęły rolę lidera w działaniach antyirackich, w krótkim czasie zdołały zapewnić sobie poparcie większości społeczności międzynarodowej, pozwalające na niemal całkowitą izolację Iraku od reszty świata. W mediach pojawiały się głosy oburzenia, iż Husajn dopuścił się tak rażącego złamania prawa międzynarodowego, doprowadzając do aneksji Kuwejtu. Od tej pory, z inspiracji czynników wojskowych, prasa światowa zaczęła zamieszczać artykuły, których autorzy twierdzili, że Irak nie ma żadnych szans, gdy dojdzie do działań zbrojnych. Argumentowano to tym, że będzie to starcie ultranowoczesnej techniki godnej XXI wieku z technika mocno przestarzała, sięgająca jeszcze nieraz czasów II wojny światowej. „Była to rzecz jasna forma psychologicznej presji na Husajna, aby ten dał za wygraną i wycofał się z Kuwejtu, bowiem uparte obstawanie przy swoim mogło tylko spowodować militarną katastrofę Iraku. Ta kampania prasowa miała też na celu uspokojenie zachodniej opinii publicznej. Chodziło o to, by przeciętny Amerykanin, Anglik czy Francuz z optymizmem patrzył w przyszłość, aby nie bał się nadchodzącego konfliktu. Rzeczywiście działania te odniosły duży sukces. Praktycznie w żadnym kraju nie zrodziła się obawa przed skutkami tej wojny, jej przebiegiem i możliwościa przedłużenia się konfliktu" ${ }^{\text {"13 }}$.

Roger Mucchielli, specjalista od spraw dezinformacji, wydał w 1972 r. mała książeczkę pt. Dywersja. Na podstawie jej fragmentów, a także komentarza do nich autorstwa Vladimira Volkoffa ${ }^{14}$, dokonanie analizy form propagandy i dezinformacji, jakich używali koalicjanci wobec Iraku w trakcie konfliktu w Zatoce, jest stosunkowo prostym zabiegiem. Przedstawiają się one następująco:

a) dezintegracja grup tworzących naród - Amerykanie próbowali skłonić szyitów i Kurdów do walki o swoje interesy;

b) dyskredytacja władzy, jej obrońców, przedstawicieli i osobistości na każdym kroku przekonywano, że Husajn jest zagrożeniem dla świata;

c) bojkotowanie każdej formy wyrażania woli przez naród - zachód, słusznie zreszta, nie uznawał referendów prezydenckich w Iraku;

\footnotetext{
${ }^{13}$ R. Bielecki, Pustynna Burza, dz. cyt., s. 70-71.

${ }^{14}$ V. Volkoff, dz. cyt., s. 94-115.
} 
d) budzenie i podsycanie wzajemnej nieufności wewnątrz grup między Kurdami, sunnitami i szyitami;

e) wprowadzanie w obozie nieprzyjacielskim rozróżnienia między przywódca, a jego ludem - koalicjanci dobitnie podkreślali, że to Husajn jest wogiem, a nie muzułmanie, Arabowie czy Irakijczycy.

Iracki dyktator także prowadził intensywną kampanię propagandowa. Nieustannie nawiązywał w niej do apokaliptycznej wizji ewentualnego konfliktu Iraku z siłami rodzącej się koalicji, który miał przynieść wrogim siłom olbrzymie straty i potwierdzić bezprzykładne męstwo żołnierzy irackich. „Odwoływał się przy tym do wojen krzyżowych i porównywal swą misję z legendarnym Salladynem (urodzonym, tak jak Husajn, w Tikrit). Groził także Stanom Zjednoczonym falą zamachów terrorystycznych oraz tym, że odeśle wszystkich żołnierzy amerykańskich $\mathrm{w}$ trumnach. Kampania ta, o czym nie wolno zapominać, skierowana była do szerokich mas arabskich i muzułmańskich, nie zaś do społeczeństw europejskich czy amerykańskiego i z tego też punktu widzenia należy uznać ją za skuteczną"

Husajn rozumiał też, jak potężnym i trwałym czynnikiem są marzenia narodu arabskiego o jedności i sile, które do dziś dzień wyraźnie konstatuja z rzeczywistością. Z tego powodu bardzo wiele miejsca w swoich przemówieniach poświęcał sprawom zjednoczenia „narodu Arabskiego”, konieczności przezwyciężania kolonialnych podziałów ${ }^{16}$, sprawiedliwego podziału bogactw oraz potrzebie przeciwstawienia się obcej interwencji ${ }^{17}$, która w przeszłości prowadziła do manipulowania i osłabiania świata arabskiego. Kampania ta przyniosła tylko częściowy skutek ${ }^{18}$, bo, jak wiemy, w koalicji antyirackiej

15 W. Szymborski, Zatoka Perska, dz. cyt., s. 133.

$16 \mathrm{~W}$ jednym z pierwszych wystąpień telewizyjnych po aneksji Kuwejtu Husajn stwierdził, że „okupacja Kuwejtu położyła kres podziałowi kolonialnemu w świecie arabskim na biedną większość i bogatą mniejszość”. Zob. P. Salinger, E. Laurent, dz. cyt., s. 143.

17 Przykładem na prowadzenie tego typu działań było przygotowanie aktu oskarżenia do sądu ludowego przeciwko Georgowi Bushowi Akt oskarżenia zawierał następujące zarzuty: wysłanie amerykańskich wojsk do rejonu Zatoki Perskiej i okupacja miejsc świętych islamu w Arabii Saudyjskiej; grożenie atakiem na Irak i naród Arabski; narzucenie Irakowi sankcji gospodarczych; wydanie CIA rozkazu spiskowania przeciwko Saddamowi. Zob. G. Bush, B. Scowcroft, Świat przeksztatcony, Politeja, Warszawa 2000, s. 379.

${ }^{18} \mathrm{~Np}$. w Jordanii wszystkie gazety wzywały do przeciwstawienia się ,„jaskrawej agresji sił imperialistycznych przeciw bratniemu narodowi irackiemu i jego mądremu kierownictwu. (...) Formalne oświadczenie analogicznej treści - Irak jest obrońcą i siła przewodnią narodu arabskiego, spełnia on historyczną rolę $\mathrm{w}$ walce $\mathrm{z}$ Wielkim Szatanem, który grozi wszystkim krajom arabskim - ogłosił także jordański parlament”. 
znalazło się też kilka państw arabskich (Syria, Egipt itd.), ale za to zaskakująco dobrze została przyjęta dotychczas Jemenie, Jordanii i wrogim dotychczas Iranie ${ }^{19}$. „Taktyka przedstawiania się jako ofiary zachodniego imperializmu oraz wzywania do świętej wojny $z$ niewiernymi, bezczeszczącymi święte miejsca islamu, znajdowała zrozumienie na szczytach władzy i u części społeczeństwa irańskiego. Reprezentantem tej grupy był duchowny przywódca Iranu - ajatollah Ali Chamenei, który wielokrotnie oskarżał USA, że to dzięki ich poparciu dla Iraku, w czasie wojny z Iranem, arogancja Husajna osiagnęła taki poziom, że zdecydował on się zająć Kuwejt. Jednocześnie nie pozostawial Amerykanom żadnych złudzeń twierdząc, że każdy, kto walczy przeciwko amerykańskiej agresji, jest zaangażowany w święta wojnę w imię Allaha, a gdy zostanie podczas niej zabity, będzie męczennikiem"20.

Saddam Husajn podjął także decyzję o zatrzymaniu wszystkich obywateli obcych państw jako zakładników. Liczył oczywiście, iż dzięki temu będzie miał wpływ na opinię publiczna w krajach koalicji, a poprzez to będzie mógł wywierać naciski na rządy poszczególnych krajów. Zakładnicy byli także „używani” dla potrzeb propagandy wewnątrzirackiej i szerzej arabskiej. Ostatecznie Husajn zwolnił kobiety i dzieci licząc, że zyska przez to pewne bardziej przyjazne reakcje zachodnich stolic. Tym razem spotkał go jednak zawód. Nie zarzucił jednak dążeń do spowodowania „pęknięć” w koalicji. Dał do zrozumienia, że obcokrajowcy mogą zostać zwolnieni, jeżeli zostaną w tej sprawie przeprowadzone negocjacje międzyrządowe. Te zabiegi Husajna nie były daremne. Żaden rząd nie zdecydował się co prawda na tego typu rozmowy, ale opinie publiczne w krajach koalicji naciskały i domagały się działań. „Kilkunastu liczących się polityków „z własnej inicjatywy" udało się do Iraku. Pierwszy był prezydent Austrii Kurt Waldheim, potem były premier Wielkiej Brytanii Edward Heath, były premier Japonii Nakasone, były prezydent Algierii Ben Bella, były kanclerz RFN Willy Brandt, a także francuski skrajny nacjonalista Jean Marie Le Pen. Za każdym razem otrzymywali oni „w darze” od

Zob. W. Giełżyński, Pierwssyy tydzień trzeciej wojny, Wydawnictwo Wojciech Pogonowski, Warszawa 1991, s. 29.

19 Prezydent Egiptu Hosni Mubarak przyznał się Amerykanom, że Saddam Husajn złożył mu pewną ofertę, którą, jak sądził, zaakceptowali królowie Jordanii - Husajn i Jemenu - Saleh. Pomysł miał polegać na tym, że w zamian za poparcie inwazji obiecywano udzial w kuwejckiej ropie oraz w zrabowanych aktywach i zasobach finansowych Kuwejtu. Egipt propozycję odrzucił.

${ }^{20}$ W. Szymborski, Zatoka Perska, dz. cyt., s. 131. 
kilkunastu do kilkudziesięciu zakładników, w zależności od tego, jaką pozycję sami zajmowali na scenie politycznej. Efekt jednak był taki, iz Husajn mógł przekonać samych Irakijczyków i spora część Arabów, że z Bagdadem solidaryzuje się znaczna część międzynarodowej opinii publicznej, czego wyrazem miały być właśnie te wizyty" ${ }^{\text {21 }}$.

Kolejna bardzo przemyślaną zagrywką Husajna było rozbudzenie nieufności koalicjantów co do szczerości poczynań Francji. W Iraku uznano, iż kraj ten jest jednym z najsłabszych ogniw koalicji. Wnioskowano tak na podstawie dotychczasowej bardzo proarabskiej postawy Paryża, jego świetnych stosunków z Bagdadem oraz antyamerykańskości i silnego poczucia własnej niezależności. Sądzono także, że we Francji obawiano się wysokich kosztów finansowych konfliktu i utraty wpływów w świecie arabskim. 22 października Bagdad zwolnił wszystkich francuskich więźniów. W ten sposób stworzono wrażenie, że doszło do tajnych negocjacji i że Francuzi stosuja podwójna grę, a więc że reszta koalicji nie powinna im ufać. Na niewiele zdały się późniejsze tłumaczenia Mitteranda, że do niczego nie doszło.

Koalicjanci rozpoczęli operację „Pustynna Burza” 17.01.1991 r. Przez ponad miesiąc trwały naloty i bombardowania. Najbardziej dramatycznym epizodem działań irackich była próba globalizacji konfliktu poprzez wciagnięcie doń Izraela. „Atak Iraku na Izrael był chytrze pomyślaną próbą oddzielenia krajów arabskich od koalicji antyirackiej poprzez wywołanie bezpośredniej reakcji militarnej Izraela lub też uzyskania poparcia ze strony radykalnych krajów arabskich",22. Irak systematycznie wystrzeliwal rakiety typu SCUD na terytorium Izraela. Reżim oraz proirackie media arabskie wykorzystały to także do celów propagandowych, nadwerężając zaufanie do amerykańskiego systemu obrony przeciwrakietowej. $\mathrm{Na}$ szczęście dzięki intensywnym zabiegom dyplomatycznym Izrael postanowił pozostać na uboczu. Podjęcie akcji odwetowej przez Izrael byłoby bardzo po myśli Husajna i oznaczałoby z pewnościa kres koalicji, jako że trudno było wyobrazić sobie współdziałanie Izraela i państw arabskich przeciwko Irakowi. Dla Husajna była to ostatnia i zarazem najpoważniejsza szansa poróżnienia członków koalicji i powiązania kwestii Kuwejtu z resztą znajdujących się w spektrum bliskowschodnich sprzeczności i sporów. Co więcej, „Stany Zjednoczone nie miały pojęcia, na czym mogłaby polegać eskalacja działań Iraku w wypadku, gdyby siły koalicji próbowały usunąć reżim

\footnotetext{
${ }^{21}$ R. Bielecki, dz. cyt., s. 50-51.

22 Brent Scowcroft, doradca prezydenta Georga Busha do spraw bezpieczeństwa narodowego. Zob. G. Bush, B. Scowcroft, dz. cyt., s. 465.
} 
Husajna ze sceny. Wprawdzie w tej kwestii Waszyngton otrzymał informacje od wywiadu izraelskiego, ale nigdy nie rozumiał całej rozgrywki. 25 lutego 1991 roku Irak wystrzelił na izraelską pustynię Negew rakietę z betonową głowica. Ten „ślepy” ładunek miał masę $\mathrm{i}$ profil głowicy biologicznej. Zdaniem niektórych ekspertów, jego odpalenie było ostrzeżeniem, że jeśli koalicjanci ruszą na Bagdad, aby odsunąć reżim Husajna od władzy, uruchomi on cały swój arsenał broni bakteriologicznej przeciwko Izraelowi. Ale nie było, co do tego całkowitej pewności, czy należało to tak interpretować"23.

Saddam Husajn wykorzystał naloty i bombardowania koalicjantów do własnych celów propagandowych. Podkreślano, że Irak wciąż trwa, że nie załamał się, a wojska irackie stawiają czoło olbrzymiej armii, w której było m.in. pół miliona Amerykanów. I nie miało tu znaczenia, że nie doszło jeszcze do walk lądowych, a wojna oznaczała na razie wyłącznie bombardowania. „Ważne było to, że Irak nie został pokonany, że, przeciwnie, Irakijczycy wytrzymywali zmasowane naloty i moga zadawać koalicji „dotkliwe straty”. Tak bowiem oceniano kilka strąconych samolotów i rakiety, które spadły na Izrael”24. W styczniu iracka telewizja pokazała siedmiu schwytanych pilotów wojskowych koalicji. Ich wygląd sugerowal, że byli bici, a może nawet torturowani. Podawali swoje nazwiska i stopnie, a także, pod przymusem, przyznawali się do „popełnionych zbrodni”. Obrazy te wywołały wśród milionów obywateli koalicji, zwłaszcza Amerykanów, którzy mieli skojarzenia z Wietnamem, pragnienie zemsty i chęć odwetu.

Do sporego „zamieszania” doprowadziła także radziecka krzątanina dyplomatyczna. Husajn postanowił wykorzystać ją do swoich celów. W lutym, po raz pierwszy od poczattku konfliktu zgodził się zaaprobować rezolucję Rady Bezpieczeństwa ONZ nakazującą wycofanie wojsk irackich z Kuwejtu. Zgoda ta była jednak obwarowana licznymi i niemożliwymi do spełnienia warunkami. Irak zażądał m.in.: anulowania wszystkich antyirackich rezolucji ONZ, anulowania długów zagranicznych, odbudowy na koszt „agresorów” zniszczeń wojennych itd. Tym samym Husajn po raz kolejny dowiódł, że mylą się ci, którzy uważaja go za nierozgarniętego szaleńca. Pokazał, że jest wprawionym i przebiegłym graczem. Dzięki temu zamieszaniu udało mu się odwlec na jakiś czas ofensywę lądowa wojsk koalicji, a przede wszystkim znowu pokazał się Arabom jako wytrwały bojownik ich sprawy i wzmocnił nastroje pacyfistyczne na Zachodzie.

${ }^{23}$ P. Bracken, Pożar na Wschodzie, Politeja, Warszawa 2000, s. 118.

${ }^{24}$ R. Bielecki, dz. cyt., s. 96. 
Pod koniec lutego wojska lądowe koalicji pod dowództwem gen. Schwarzkopfa przeszły do ofensywy, która w ciagu niespełna 100 godzin doprowadziła do wyzwolenia Kuwejtu i całkowitego obezwładnienia armii irackiej - Husajn musiał się poddać ${ }^{25}$. Propaganda iracka głosiła jednak, że to koalicjanci zostali zmuszeni do poddania $\operatorname{się~}^{26}$, a relacje telewizyjne wskazywały, że Arabowie w to wierza. 21 marca 1991 roku Rada Bezpieczeństwa ONZ narzuciła Irakowi warunki zawieszenia broni, nakazując mu m.in. wypłatę ogromnych kontrybucji, a także zniszczenie wszelkiej broni masowego rażenia.

Administracja prezydenta Georga Busha, która zebrała tyle pochwał za swoje podejście do kryzysu, przedstawiła zarazem przedziwnie zmienne i ogólnikowe wytłumaczenie, w obronie czego stanęły Stany Zjednoczone i koalicjanci w Zatoce Perskiej. Chociaż początkowo prezydent Bush zastrzegal, że nie może być mowy o amerykańskiej interwencji, już kilka godzin później zmienił zdanie. „W ciagu zaledwie kilku godzin Saddam Husajn zmienił stosunek sił. Zdobywając kuwejckie pola naftowe przejął kontrolę nad około jedna piątą ilości wydobywanej w świecie ropy. Inwestycje emiratu mogły stać się ponadto ogromna zdobyczą wojenną i narzędziem presji na gospodarki krajów zachodnich"27. Kiedy ogłosił, że zamierza wysłać w rejon Zatoki amerykańskie siły zbrojne, zastrzegał, że czyni to w czysto obronnych celach. Później jednak lista tych celów, czasami wyrażanych otwarcie, czasami jedynie sugerowanych, zaczęła powiększać się z dnia na dzień i stawały się one coraz bardziej ambitne. W końcu Bush określił inwazję Iraku jako zagrożenie dla amerykańskiego stylu życia. Nie wahał się porównać podbojów Husajna do agresji hitlerowskich. „Tak więc, jak pisał Teodor Draper, rząd poczuł się zmuszony do zagrania co sił na

25 „Uświadommy sobie, co się działo podczas ostatecznego amerykańskiego ataku na pozycje irackie podczas wojny w Zatoce: żadnych fotografii, żadnych dziennikarskich relacji, tylko huk czołgów ze spycharkami przyczepionymi od frontu jak tarcze, przetaczających się ponad irackimi okopami, grzebiącymi po prostu tysiące żołnierzy w ziemi i piasku - to, co się naprawdę działo, uznano najprawdopodobniej za zbyt okrutne w swej czysto mechanicznej wydajności, zbyt odmienne od standardowych wyobrażeń o heroicznych potyczkach twarzą w twarz. Uznano, że takie obrazy mogą zbyt mocno wstrzasnąc opinią publiczna, narzucono więc całkowite embargo dla mediów... Gdy Jean Baudrillard nazwał wojnę w Zatoce nie-wydarzeniem, to jego określenie może być odczytywane w tym sensie, że traumatyczne obrazy pokazujące realność tej wojny były totalnie cenzurowane”. Zob. S. Źiźek, Against the Double Blackmail; E. Bendyk, Wojna wirtualna, „Res Publica Nowa”, 2002, nr 4.

${ }^{26}$ Radio Bagdad głosiło, że „Bush ogłosił rozejm po otrzymaniu lekcji, która przeraziła go militarnie i politycznie”. Zob. P. Salinger, E. Laurent, dz. cyt., s. 214.

27 Tamże, s. 81-82. 
pełnej skali doktrynalnych organów: narodowym bezpieczeństwie, katastrofie gospodarczej, wolności żeglugi, oddaniu sprawie pokoju i dobrobytu naszych przyjaciół i sprzymierzeńców, obronie pokoju. (...) Caspar W. Weinberger dorzucił, że jego następca Richard Cheney móg1 jeszcze użyć hasła „przywództwo”. Weinberger powiedział komisji kongresowej, że stawką było „przewodzenie wolnemu światu w przeciwstawianiu się siłom anarchii i tyranii" 28 . Zachodni dziennikarze pisali, że prawdziwa przyczyną takiej, a nie innej postawy Stanów Zjednoczonych była konieczność utrzymania dostępu do ropy, niezbędnej dla gospodarki Zachodu, i potrzeba efektywnej kontroli jej cen. Badacze przyznaja, że gdyby Kuwejt był jakimś krajem afrykańskim w środkowej części Sahary, nieposiadającym ropy, to do jego ochrony nie wysłano by nawet jednego amerykańskiego żołnierza. „Tak więc USA zaangażowały się w Zatoce nie po to, aby bronić zasady suwerenności czy też spowodować powrót władców Kuwejtu do ich pałaców. (...) Amerykańskie siły zbrojne nie zostały tam również wysłane po to, aby bronić prawowitego rządu Arabii Saudyjskiej przed dalszą ekspansja Saddama Husajna"29.

W trakcie wojny prezydent Bush wielokrotnie powtarzał, iż nie można dopuścić do przetrwania rządów Husajna. Opinia publiczna mogła to odczytać jako zakamuflowane wezwanie Irakijczyków do wystapienia przeciwko swemu przywódcy. I tak to prawdopodobnie zostało zrozumiane przez Kurdów i Szyitów, którzy doprowadzili do wybuchu powstań przeciwko reżimowi. Niestety jasnym było, że hojnie dotowana opozycja iracka to partner niepewny, złożony z ponad 70 ugrupowań, które spiskują i reprezentują wszystkie opcje polityczne i etniczne oraz że nie są one w stanie się zorganizować. „To był najważniejszy powód, dla którego USA nie doprowadziły do końca operacji Pustynna Burza - nie miały politycznej alternatywy dla Iraku Saddama”30. Ale czy to wszystko? „Można się zastanawiać, dlaczego Bush senior nie zniszczył reżimu? Z punktu widzenia sztuki wojskowej, zdobycie Bagdadu w momencie zakończenia operacji nie przedstawiało najmniejszego problemu. Odpowiedź wydaje się być jedna - interes. USA od lat rozgrywają własna partię na Bliskim Wschodzie. Husajn był im potrzebny osłabiony, ale żywy"31. Potencjalny rozpad Iraku mógłby

28 J. Miller, L. Mylroie, Saddam Husajn. Wojna w Zatoce, Supernowa, Warszawa 1991, s. 209-210.

${ }^{29}$ Tamże, s. 212.

${ }^{30}$ Ch. Boltanski, P. Riche, Dyktator nie do zdarcia, „Gazeta Wyborcza”, 22.01.1993.

${ }^{31} \mathrm{H}$. Piecuch, Kulisy terroryzmu. V atakuje. 18 minut, które wstrzasnety Ameryka, Exlibris, Chicago-Warszawa 2002, s. 106. 
pociagnąć za sobą trudne do przewidzenia konsekwencje. W tej sytuacji administracja Busha jednoznacznie stwierdziła, że oba powstania sa wewnętrzną sprawą Iraku i nie ponosi za nie odpowiedzialności. „Krytycy utrzymywali, że zachęcaliśmy separatystów szyickich i kurdyjskich do powstania, a następnie nie dotrzymaliśmy danej im obietnicy, kiedy powstali przeciwko Saddamowi. Prezydent Bush wielokrotnie oświadczał, że o losie Saddama zdecyduje naród iracki. Od czasu do czasu dawał do zrozumienia, że powitalibyśmy z ulga odsunięcie go od władzy, lecz z czysto praktycznych względów nigdy nie obiecywaliśmy udzielenia pomocy powstańcom" ${ }^{\text {32 }}$. Przywódca iracki szybko zorientował się, że na jego utrzymaniu się przy władzy, ściśle powiązanym $\mathrm{z}$ integralnością Iraku, zależy coraz większej grupie uczestników gry w rejonie Zatoki ${ }^{33}$. Z właściwą sobie „skutecznością" iracki dyktator przystapił do działań przeciwko obu społecznościom. Kiedy świat dowiedział się z raportów organizacji praw człowieka o nowych zbrodniach reżimu, koalicjanci wymusili na władzach Iraku stworzenie tzw. stref bezpieczeństwa. Zastanawiające jest tu milczenie świata, a jeszcze bardziej fakt, iż obserwatorzy dowiedzieli się o ludobójstwach - przecież można było to zrobić „po cichu”. Zasadnym wydaje się więc przypuszczenie, że Husajn specjalnie się z tym nie krył. „Administracja amerykańska znalazła się w trudnej sytuacji, a część prasy zarzucała jej wręcz współpracę z Husajnem. Popularność samego prezydenta, która w czasie Pustynnej Burzy sięgała niemal 90\%, po masakrach Kurdów zaczęła dramatycznie spadać. Pojawiły się liczne przypuszczenia, że Amerykanie nie posiadaja jasnej wizji ustabilizowania sytuacji w rejonie Zatoki”' ${ }^{\prime 3}$. Bush mimo późniejszej stanowczości i nieustępliwości wobec dyktatora, zapłacił porażką w wyborach na następną kadencję - a Husajn mógł się cieszyć, że mocno się do tego przyczynił. George Bush mówi dziś, że nie żałuje swojej decyzji o zakończeniu Pustynnej Burzy po 100 godzinach. Rezygnacje z obalenia Husajna tłumaczono wówczas ograniczeniami mandatu ONZ, który przewidywał tylko wyzwolenie Kuwejtu. Bush mówi, że bał się pogrążenia w długiej i krwawej walce partyzanckiej. Ile w tym prawdy, kto wie? Jednak niezdecydowana postawa koalicji kłóciła się z tradycyjna strategia kończenia działań militarnych bezsprzecznym zwycięstwem. Nie było także wyraźnego jej zakończenia w postaci uroczystego aktu kapitulacji.

${ }^{32}$ G. Bush, B. Scowcroft, dz. cyt., s. 502.

${ }^{33}$ Por. W. Szymborski, Kryzys iracki, „Sprawy Międzynarodowe”, 1997, nr 4.

34 Tenże, Zatoka Perska, dz. cyt., s. 139. 
Wbrew licznym opiniom podkreślającym konieczność zniesienia sankcji po zakończeniu działań militarnych $z$ uwagi na negatywne konsekwencje dotykające ludność Iraku, nie można wykluczać, że sam dyktator pozostawał zainteresowany ich dalszym utrzymaniem. Zdołal już przekonać się o tym, że system sankcji integruje społeczeństwo irackie wokól niego i umożliwia mu przekonywanie narodu co do zewnętrznych przyczyn istniejących problemów. Ich zniesienie mogłoby obnażyć jego reżim i uczynić go bezpośrednio odpowiedzialnym za sytuację wewnętrzna. „Za każdym razem iracki przywódca twierdząc, że jego rząd zrealizował już w pełni rozbrojeniowy plan ONZ, mobilizował własne społeczeństwo pod hasłami przeciwstawienia się amerykańskiej ingerencji w wewnętrzne sprawy kraju. Propaganda iracka przekonała społeczeństwo, że to USA, Izrael i ONZ, poprzez bezzasadne utrzymywanie sankcji, winne są stale pogarszającej się kondycji gospodarczej kraju i niehumanitarnych warunków życia ludności. Za pomoca tych argumentów Husajn starał się również wpłynąć na nieprzychylną mu część świata arabskiego i osłabić jedność stałych członków Rady Bezpieczeństwa"35. Udało mu się to. Rozbieżności w Radzie coraz częściej ujawniały się podczas debat na temat dalszego stosowania sankcji lub przy okazji każdego kolejnego kryzysu. USA i Wielka Brytania utrzymywały twarda i bezkompromisowa postawę wobec Iraku uznajacc, że warunkiem zniesienia sankcji było całkowite wypełnienie rezolucji rozbrojeniowych. Pozostali członkowie Rady Bezpieczeństwa byli skłonni, z różnych powodów, do przyjęcia postawy bardziej kompromisowej. Nie ulega watpliwości, że Francja i Rosja pragna prowadzić własna politykę wobec rejonu Zatoki. Dopóki bowiem nie nastapi zniesienie sankcji, Irak nie spłaci Rosji 10 mld dolarów długu, a rosyjskie firmy nie skorzystaja na podpisanych już kontraktach o wartości dwukrotnie większej. Do wejścia w iracki biznes naftowy szykowały się też francuskie koncerny Elf i Total, a Bagdad jest winien Francji 7,5 mld dolarów. „Irak kusił zyskami, tymczasem USA, jakby na potwierdzenie oskarżeń o hegemonię ogłosiły chęć ukarania francuskiego Totalu i rosyjskiego Gazpromu za inwestowanie na irańskich polach naftowych. Dlatego, podczas gdy Waszyngton i Londyn wysyłały w rejon Zatoki Perskiej kolejne okręty wojenne i samoloty, Paryż i Moskwa mówiły o konieczności dialogu i >światełka na końcu tunelu<, które trzeba Bagdadowi zapalić, by wykazał chęć współpracy, a ludności żyło się spokojniej’36. W tym wszystkim pewnym paradoksem

\footnotetext{
35 Tenże.

36 R. Stefański, Saddam mychodzi z klatki, „Gazeta Wyborcza”, 28.11.1997.
} 
był też fakt, że znaczna część francuskiej broni używanej przez Husajna w czasie wojny należała de facto do Francji, gdyż Irakijczycy zwlekali z zapłata.

$\mathrm{Na}$ temat wojny w Zatoce w 1991 roku padło już wiele opinii i komentarzy. Jedni sądza, że była to „brudna wojna”, w której nie było zwycięzców, byli tylko przegrani. Inni, że było to wspaniałe zwycięstwo. Trudno jest ocenić, które opinie są bliższe prawdy, a które od niej odbiegaja. Wynika to w dalszym ciagu z braku dostępu do tajnych materiałów wojskowych. Niemniej jednak można pozwolić sobie na stwierdzenie, że w każdej opinii tkwi odrobinka prawdy.

Konflikt w Zatoce Perskiej w 1991 roku pierwszym konfliktem nowego typu. Wyznaczył on zupełnie nowe kierunki prowadzenia działań, wojna stała się operacją rozgrywaną wielopłaszczyznowo. „Realne zmagania, które na skutek bezwzględnej dominacji wojsk koalicyjnych przekształciły się $\mathrm{w}$ przemysłowa utylizację cywilizacyjnych odpadów, zostały wyłączone z bezpośredniego oglądu opinii publicznej. Trafiły do niej później w formie zdekonstruowanej jako m.in. gry i multimedia. Drugi front tej wojny ustalił się w przestrzeni symbolicznej, zdominowanej przez media, które uczyniły z tej operacji wydarzenie globalne. Paul Virillio stwierdził, że ,wojna ta fizycznie odbyła się w Kuwejcie, ale równocześnie rozgrywała się na całym świecie. Miejscem ostatecznego zwycięstwa było nie pole zmagań, ale ekran”. W istocie to jednak dopiero łączny wynik zmagań, brutalnej rzezi i bombardowania widzów na całym świecie obrazami, doprowadził do sukcesu. Wrogowi została narzucona siła wola, a cały świat przyjął symbolikę zwycięzców za swoja" ${ }^{37}$.

Henryk Piecuch, specjalista od spraw wojskowych i służb specjalnych, twierdzi natomiast, że wojna ta okazała się zarówno zwycięstwem, jak i porażką Stanów Zjednoczonych oraz całej koalicji. Zwycięstwem militarnym, ponieważ wyzwolono terytorium Kuwejtu, co było najważniejszym zadaniem koalicji. Co więcej, uczyniono to przy naprawdę niewielkich stratach własnych, które szybko udało się zniwelować. Porażką propagandową, gdyż strona przeciwna również odniosła sukcesy, jak np. umocnienie autorytetu Saddama Husajna wśród Irakijczyków i Arabów, wzrost nastrojów antyamerykańskich w świecie arabskim, czy brak wyraźnego zakończenia konfliktu w postaci uroczystego podpisania aktu kapitulacji. „Wojna w Zatoce przyczyniła się do wzrostu liczby wrogów USA na świecie o dalsze kilkaset milionów. A to już nie jest bez znaczenia we współczesnym teatrze globalnych

${ }^{37}$ E. Bendyk, Wojna wirtualna, dz.cyt. 
działań wojennych - działań toczących się w atmosferze chaosu i szumu informacyjnego. A wszystko to pod okiem kamer telewizyjnych, co znakomicie ułatwi manipulację i dezinformację, tak potrzebną do sterowania $>$ gniewem ludu $<" 38$. Właśnie ta opinia wydaje się być najbliższa prawdy.

${ }^{38}$ H. Piecuch, dz. cyt., s. 224-225. 